\title{
SISTEM INFORMASI TUNGGAKAN PREMI NASABAH MENGGUNAKAN PEMROGRAMAN VISUAL DELPHI PADA ASURANSI JIWA BERY ANGGARA 1446
}

\author{
BERY ANGGARA PRATAMA \\ 785567869 \\ University Of Mitra Indonesia \\ Beryanggarapratama.student@umitra.ac.id
}

\begin{abstract}
Abstraksi
Penelitian ini untuk menyelesaikan permasalahan pembayaran premi nasabah pada asuransi jiwa bersama berry anggara 1446 cabang Lampung. Selama ini para nasabah masih direpotkan dalam hal pembayaran preminya dikarenakan masih adanya sistem pembayaran yang tidak memberikan kemudahan dan perhitungan premi yang masih keliru, sehingga perusahaan juga berdampak masalah dalam hal pendapatan yang tidak konsisten karena pembayaran premi nasabah merupakan pendapaan yang sangat penting terhadap kelangsungan program perusahaan.

Untuk mendukung sistem informasi ini penulis melakukan studi kepustakaan dengan cara membaca dan mempelajari dari berbagai buku juga bersumber literatur yang berkaitan dalam sistem dan studi lapangan dengan cara melakukan konsultasi kepada pihak yang berkompeten diperusahaan serta melakukan survei ke perusahaan.

Software yang dirancang ini menghasilkan suatu sistem yang dapat menyelesaikan cara pembayaran premi nasabah yang selama ini selalu menunggak, sehingga mempengaruhi perusahaan dalam mengembangkan program-program asuransi yang lainnya.

Dari penelitian ini dapat ditarik kesimpulan bahwa dengan sistem yang dirancang ini dapat membantu masalah penunggakan premi nasabah serta dapat membantu nasabah menerima tanda bukti yang otentik sehingga meningkatkan keyakinan para nasabah untuk ikut dalam program-program asuransi yang lainnya. Walaupun sistem ini sudah mampu menyelesaikan masalah, namun masih kurang sempurna karena sistem ini belum didukung secara on-line ataupun mobile, karena keterbatasan waktu dan kesibukan para nasabah dalam menjalankan aktifitasnya sehari-hari dapat menyebabkan ketidak konsistennya pendapatan perusahaan setiap bulanya karena pembayaran premi ini merupakan pendapatan utama perusahaan.
\end{abstract}

Kata Kunci : Premi, Nasabah, Tunggakan, Sistem Informasi pembayaran 


\section{INTRODUCTION \\ 1. PENDAHULUAN}

Asuransi berasal dari kata asing yaitu insurance atau asurance yang berarti

transaksi pertanggungjawaban yang melibatkan dua pihak, yaitu pihak penanggung dan pihak tertanggung. Pihak penanggung menjamin pihak tertanggung, bahwa ia akan mendapatkan pergantian terhadap suatu kerugian yang akan dideritanya. Sebagai kontra prestasinya tertanggung diwajibkan membayar uang kepada si penanggung, yaitu besarnya sekian persen dari nilai pertanggungan yang biasa disebut premi.

Meskipun penerimaan premi banyak mengalami resiko (kerugian) akan tetapi berbagai alternatif pasti akan digunakan untuk menanggulangi penurunan penerimaan premi yang berhubungan erat

dengan pendapatan asuransi dalam mengoperasikan kegiatan yang telah direncanakan sebelumnya. Diantara hal yang

menyebabkan ketidak efisiensian penerimaan premi asuransi.

Penulis hanya membatasi masalah mengenai premi yang menunggak membayar premi ansuransi jiwa yang dapat menunjang pendapatan asuransi di PT. Asuransi Jiwa Bersama berry anggara 1446 cabang Lampung. pada jenis produk ansuransi mita cerdas. Penelitian ini mempelajari bagaimana sistem yang sedang berjalan penerimaan premi sudah efektif dan efisienkah serata bagaiman cara merancang dan membuat suatu sistem informasi yang dapat mempermudah penunggakan premi pada PT. Asuransi Jiwa Bersama Bumi Putera 1912 cabang Binjai.

\section{LANDASAN TEORI}

\subsection{Pengertian Sistem}

Sebuah sistem sangat diperlukan bagi

3.

setiap instansi, baik itu instansi pemerintahan maupun swasta. Karena

dengan adanya sebuah sistem pelaksanaan suatau pekerjaan dapat terselesaikan dengan baik. Menurut Menurut Jugiyanto Hartono (2001:1) "Sistem adalah jaringan kerja prosedur-prosedure yang slaing berhubungan, berkumpul bersama-sama untuk melakukan suatu kegiatan atau sasaran tertentu".

Sedangkan menurut Kursini (2007:11) "sistem adalah sebuah tatanan yang terdiri atas sejumlah komponen fungsional (dengan tugas/fungsi khusus) yang saling berhubungan dan secara bersama-sama bertujuan untuk memenuhi suatu proses atau pekerjaan bagi penerimany".

\subsection{Pengertian Informasi}

Menurut menurut Sutanta (2003:9) mengatakan bahwa "Informasi adalah data yang telah diolah menjadi suatu bentuk yang berarti bagi penerimanya dan bermanfaat dalam pengambilan keputusan pada saat sekarang maupun saat yang akan datang".

Dari teori diatas dapat dikatakan bahwa sebuah informasi itu merupakan sekumpulan data-data yang telah diproses menjadi sebuah bentuk yang memiliki arti bagi penerima informasi apapun dan siapapun sipenerima informasi tersebut sebagai bahan pertimbangan dalam pengambilan sebuah keputusan dari suatu tindakan.

\subsection{Pengertian Sistem Informasi} Pengertian sistem informasi menurut Jogiyanto dalam sebuah situs (http://syahnanweb.blogspot.com/200 8/04/la ndasan-teori-sisteminformasi. html) yaitu "Sistem informasi adalah suatu sistem

didalam suatu organisasi yang mempertemukan kebutuhan pengolahan transaksi harian, mendukung operasi bersifat manajerial dan kegiatan strategi dari suatu organisasi dan menyediakan pihak luar tertentu dengan laporanlaporan yang diperlukan".

Suatu sistem informasi (SI) atau

information system (IS) merupakan aransemen dari orang, data, prosesproses, dan antar muka yang berinteraksi mendukung dan memperbaiki beberapa operasi sehari hari dalam suatu bisnis termasuk mendukung memecahkan soal dan kebutuhan pembuat keputusan manejemen dan para pengguna yang berpengalaman di bidangnya.

\section{LITERATURE REVIEW}

Pengertian Data dalam Edhy Sutanta, (2004;5) mendefenisikan "Data adalah sebagai bahan keterangn tentang kejadian nyat atau fakta-fatkat yang dirumuskan dalam sekelompok lambang tertentu yang tidak acak yang menunjukan jumlah, tindakan, atau hal". Data dapat perupa catatan-catatan dalam kertas, buku, atau tersimpan sebagai file dalam basis data.

\subsection{Pengertian Basis Data}

Basis data (database) menurut Edhy Sutanta, $(2004 ; 18)$ dapat dipahami sebagai "suatu kumpulan data terhubung (interrelated data) yang disimpan secara bersama-sama pada suatu media", tanpa suatu kerangkapan data (kalaupun ada maka kerangkapan data tersebut harus seminimal mungkin dan terkontrol (controlled redudncy), data di disimpan dengan caracara tertentu, sehingga mudah untuk digunakan/atau ditampilkan kembali; dapat digunakan oleh satu atau lebih program apliksi secara optimal.

\subsection{Pengertian Relasional Database}




\section{Manual Books Article Task}

Menurut Stephem dan Plews dalam Janner dan Paryudi $(2006 ; 1)$ menyatakan bahwa " Basis data adalah mekanisme yang digunakan untuk menyimpan informasi atau data".

\subsection{Kamus Data}

Menurut Tata Sutabri (2004:172), ”Apabila didefenisikan, kamus data adalah katalog fakta tentang data dan kebutuhan-kebutuhan informasi dari suatu sistem informasi". Kamus data dibuat pada tahap analisis sistem dan digunakan baik tahap analisis maupun pada tahap perancangan sistem. Berikut simbol-simbol yang digunakan dalam pembuatan kamus data, diantaranya :

\subsection{Hirarki Data}

4. field/atribut/data item, merupakan unit terkecil yang disebut data,yang tidak dapat dipecah lagi menjadi unit lain yang bermakna.

5. byte, merupakan sekumpulan bit yang secara konvensional terdiri atas kombinasi delapan bit yang menyatakan sebuah karakter dalam memori $(1$ byte $=$ 1 karakter)

6. bit, adalah sistem binner yang terdiri atas dua macam nilai, yaitu 0 dan 1 .

\subsection{Diagram Konteks}

Pengertian diagram kontek adalah suatu diagram alir yang menggambarkan aliran sistem kerja yang ada. Diagram kontek terdiri atas :

1. Diagram Konteks / Level 0, ini mengambarkan sumber dan arah data yang diproses secara umum dari keseluruhan sistem yang ada.

2. Diagram Nol / Level 1, ini di buat untuk menggambarkan tahapan proses yang terdapat dalam doagram konteks dengan penjabaran yang lebih teperinci.

3. Diagram Detail / Level 2, ini menggambarkan proses arus data delang lebih terperinci lagi dari levellevel yang sudah ada.

\subsection{Data Flow Diagram}

Data Flow Diagram (DFD) adalah diagram yang menggunakan notasi-notasi untuk menggambarkan arus dari data sistem.

\subsection{Pengertian Flowchart}

Pengertian flowchart menurut http: //ericute.files.wordpress.com/ 2009/10/ pert1-algol.pdf Adalah "Bagan-bagan yang mempunyai arus yang menggambarkan

langkah-langkah penyelesaian suatu masalah". Flowchart merupakan cara penyajian dari suatu algoritma

\section{Kegiatan Operasional}

Asuransi Mitra Cerdas pada berry anggara 1446 cabang Lampung. dirancang khusus

untuk mengembangkan dana yang dialokasikan untuk pendidikan bagi putraputri Pemegang Polis/Tertanggung dengan mendapatkan kesempatan memperoleh
Menurut Edhy Sutanta (2004:24), Berdasarkan tingkat kompleksitas nilai data, tingkatan data dapat disusun kedalam sebuah hirarki, mulai dari yang paling sederhana hingga yang paling komplek.

1. basis data, merupakan sekumpulan dari bermacam-macam tipe record yang memiliki hubungan antar record.

2. berkas/file, merupakan sekumpulan rekaman data yang berkaitan denngan suatu objek.

3. record, merupakan sekumpulan field/atribut/data item yang saling berhubungan terhadap obyek tertentu.

$\begin{aligned} & \text { investasi yang kompetitif } \\ & \text { pengembangan dana premi } \\ & \text { asuransi yang }\end{aligned}$
dibayarkan.
Persyaratan:
1. Jika Calon pemegang polis telah
berusia min. 21 tahun dan
maksimal saat asuransi ditambah
dengan masa asuransi

tidak lebih dari usia 65 tahun, maka berhak menjadi Tertanggung.

2. Masa asuransi min. 4 thn dan maks. 18 thn.

3. Minimal Uang Pertanggungan (UP) untuk setiap polis sebesar Rp. 50.000.000,- (lima puluh juta rupiah) sampai dengan 100.000.000,(seratus juta rupiah).

4. Premi dibayarkan dengan mata uang Rupiah.

5. Premi dapat dibayarkan secara tunggal, tahunan, setengah tahunan, dan triwulan.

6. Apabila pembayaran premi menunggak, maka akan dikenakan denda sebesar 0,37 $\%$ dari jumlah pembayaran premi.

Tabel III.1 Dana Kelangsungan Belajar

\begin{tabular}{|c|c|c|c|c|c|}
\hline \multirow{2}{*}{$\begin{array}{c}\text { Umur } \\
\text { anak } \\
\text { saat } \\
\text { masuk }\end{array}$} & \multicolumn{5}{|c|}{$\begin{array}{l}\text { Dana Kelangsungan Belajar } \\
\text { ada saat anak mencapai umur }\end{array}$} \\
\hline & 4 th & 6 th & $\begin{array}{l}12 \\
\text { th }\end{array}$ & $\begin{array}{l}15 \\
\text { th }\end{array}$ & $\begin{array}{l}18 \\
\text { th }\end{array}$ \\
\hline $1-2$ & $\begin{array}{l}5 \% \\
\text { UP }\end{array}$ & $\begin{array}{c}10 \\
\% \\
\text { UP }\end{array}$ & $\begin{array}{c}20 \\
\% \\
\text { UP }\end{array}$ & $\begin{array}{c}30 \\
\% \\
\text { UP }\end{array}$ & $\begin{array}{c}100 \\
\% \\
\text { UP }\end{array}$ \\
\hline $3-4$ & - & $\begin{array}{c}10 \\
\% \\
\text { UP }\end{array}$ & $\begin{array}{c}20 \\
\% \\
\text { UP }\end{array}$ & $\begin{array}{c}30 \\
\% \\
\text { UP }\end{array}$ & $\begin{array}{c}100 \\
\% \\
\text { UP }\end{array}$ \\
\hline $5-10$ & - & - & $\begin{array}{c}20 \\
\% \\
\text { UP }\end{array}$ & $\begin{array}{c}30 \\
\% \\
\text { UP }\end{array}$ & $\begin{array}{c}100 \\
\% \\
\text { UP }\end{array}$ \\
\hline $\begin{array}{c}11- \\
13\end{array}$ & - & - & - & $\begin{array}{c}30 \\
\% \\
\text { UP } \\
\end{array}$ & $\begin{array}{c}100 \\
\% \\
\text { UP } \\
\end{array}$ \\
\hline $\begin{array}{c}14- \\
16\end{array}$ & - & - & - & - & $\begin{array}{c}100 \\
\% \\
\text { UP }\end{array}$ \\
\hline
\end{tabular}


4. ANALISIS DAN EVALUASI

4.1 Analisis

\subsubsection{Mekanisme Sistem Yang Sedang Berjalan}

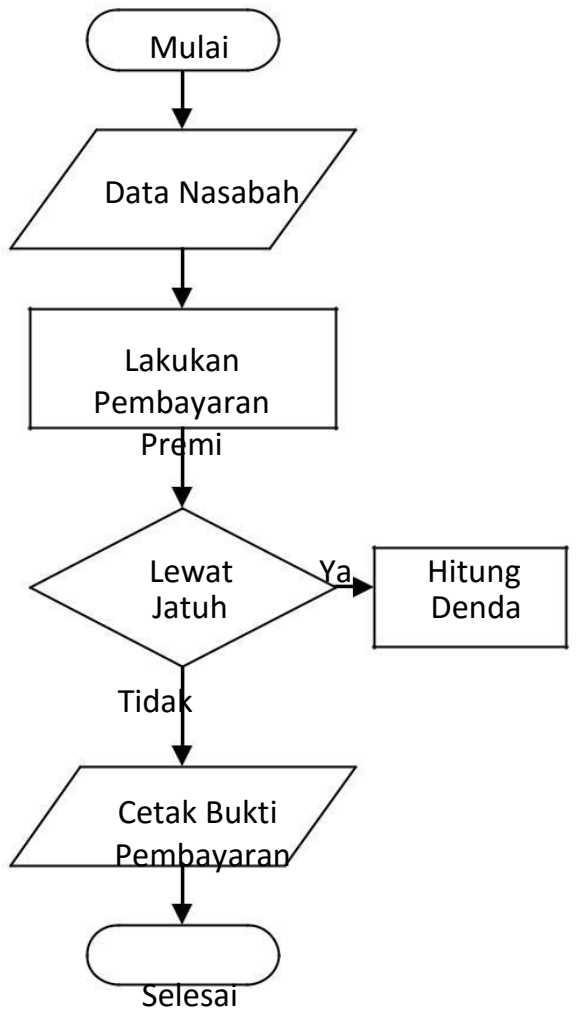

Gambar IV.1 Mekanisme yang sedang berjalan Pembayaran Tunggakan Premi

Nasabah Asuransi Mitra Cerdas

4.2 Evaluasi

4.2.1 Rancangan Diagram Konteks

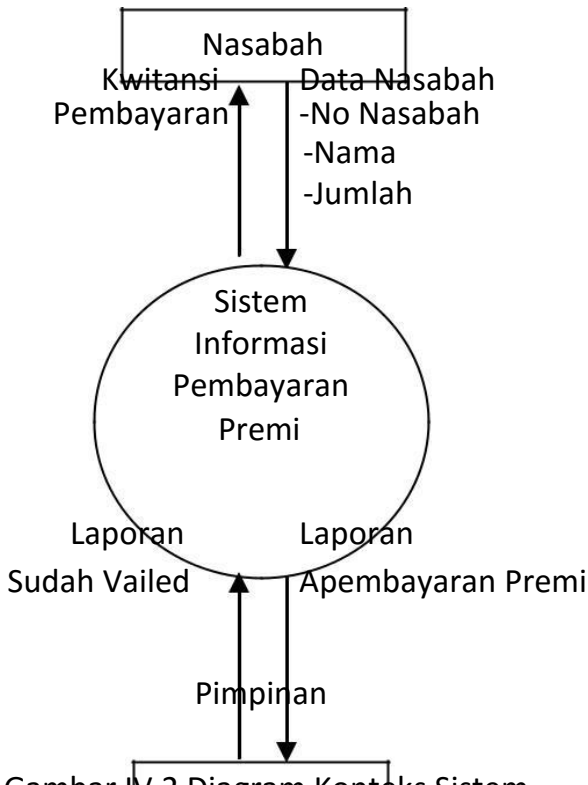

Gambar IV.2 Diagram Konteks Sistem Informasi Pembayaran Tunggakan Premi Nasabah Asuransi Mitra Cerdas
4.2.2 Data Flow Diagram Level 0

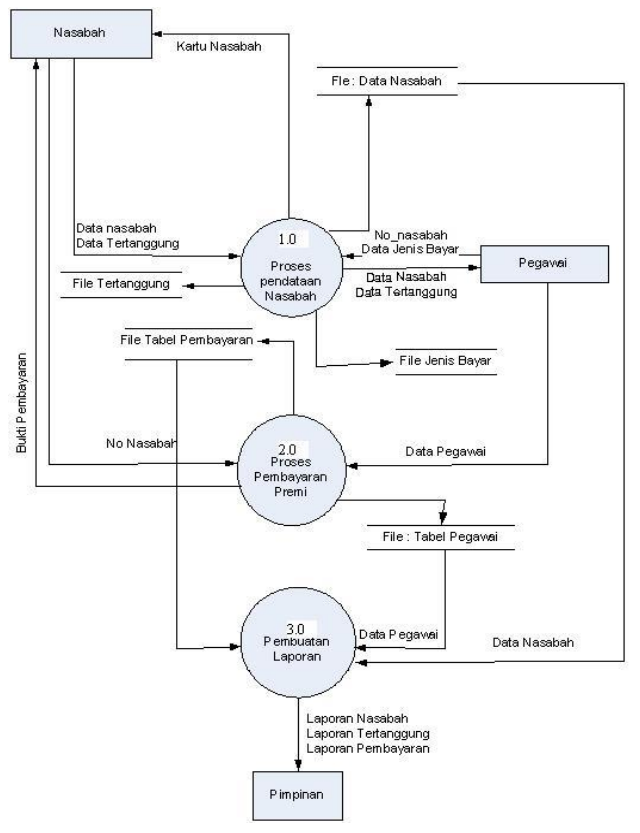

Gambar IV.2 Data Flow Diagram Level 0

\subsubsection{Rancangan Kamus Data}

1. Jenis Asuransi = @ Kode_bayar + masa

Asusransi + Jenis

Pembayaran + Besar

Premi+

Bunga_pertahun+

Bunga_Perbulan+

PremiPer_JT +

Denda_PerJ_Tempo

2.Tabel Petugas = @ ID_Petugas + nama_Petugas +

Bagian_Petugas +

Jenis Kelamin +

Tempat_Lahir +

Tanggal_Lahir.

3.Data Nasabah = @No_Nasabah +Nama

Nasabah +

Tanggal_Mulai +

Tanggal_Berakhir +

Jenis Kelamin +

Tempat_Lahir +

Tanggal_Lahir +

Usia + Pekerjaan +

Alamat Rumah +

RT/RW + Kelurahan

+ Kecamatan + Kota

+ No_Tlp_Rmh +

No_HP +

Nama_Perusahaan +

Alam_Tpt_Krj + 


\section{Manual Books Article Task}

4.Tabel $\begin{gathered}\text { Tertanggung @ } \\ \text { Nama_Tertanggung }\end{gathered}$
Jenis_kelamin
Tempat_Lahir
Tanggal_Lahir + Usia
+ Nama_Ayah/Ibu +
Pekerjaan
Tpt_Lahir_ayah_Ibu +
Tgl_lahir_Ayah_ibu +
Usia_ayah_Ibu +
No_Nasabah

5. Pembayaran Premi = @ No_Bayar + @@No_Nasabah+ BesarPremi+ Pemb_ke+ Tgl_Jatuh_temp+ Tgl_bayar+ Keterlambatan Denda_Persen + Besar Denda + Total bayar + Id_Petugas

\subsubsection{Rancangan Relationship Database}

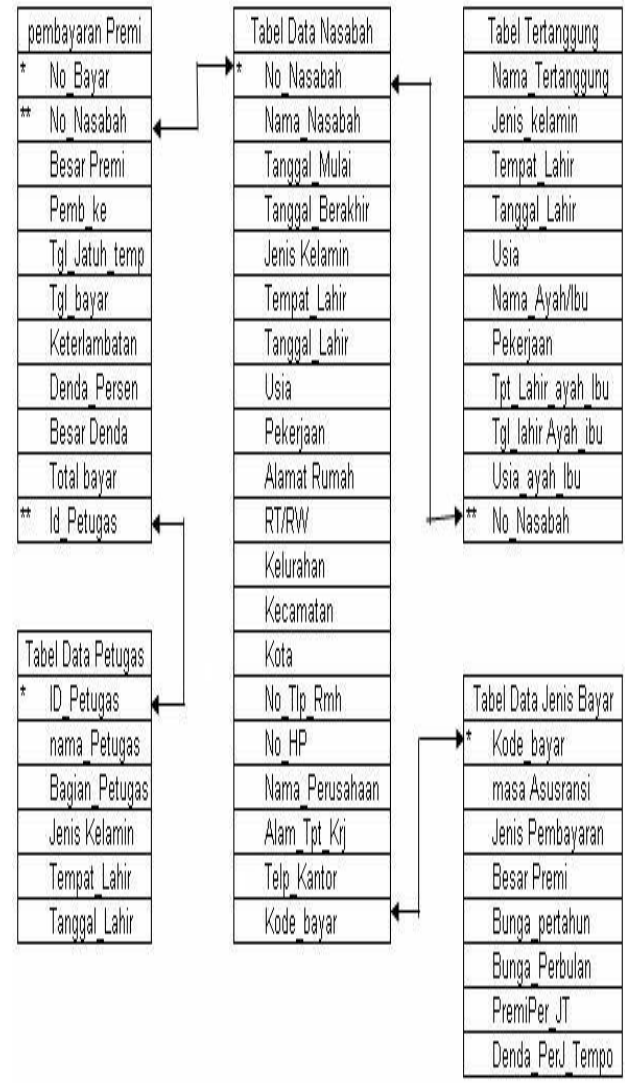

Gambar IV.3 Relasi Tabel Sistem Informasi Pembayaran Tunggakan Premi Nasabah Asuransi Mitra Cerdas

\subsubsection{Form Input Data Pembayaran} Premi

\section{RESULT}

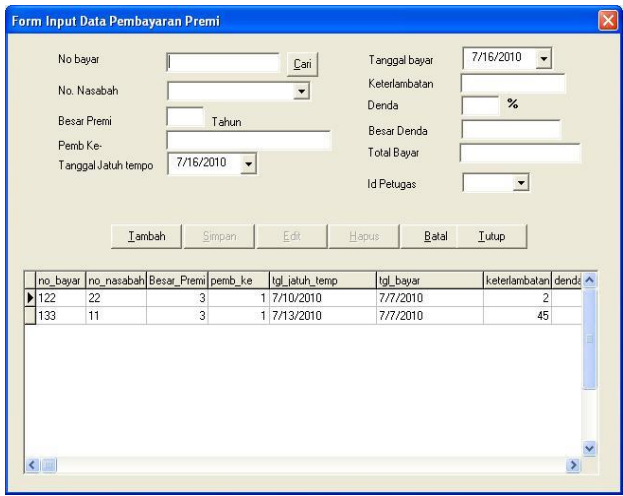

Gambar IV.4 Form Input Pembayaran Premi

\subsubsection{Output Rekapitulasi Pembayaran} Premi Perbulan

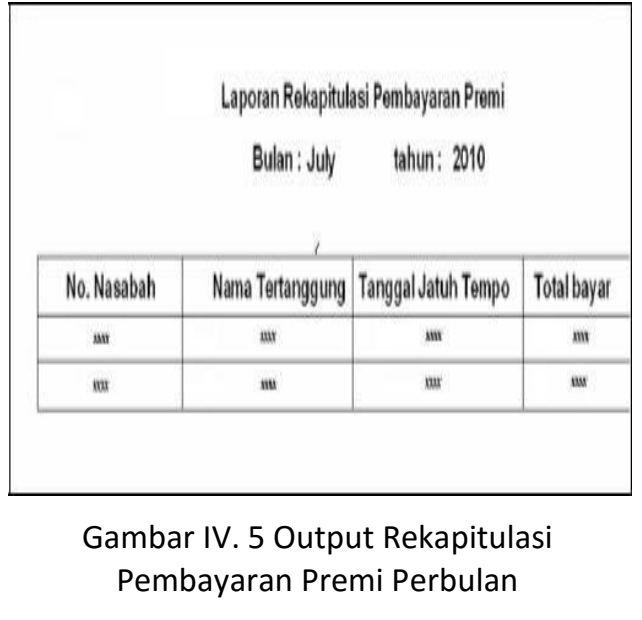

\section{KESIMPULAN}

\section{CONCLUSION}

5. 1 Kesimpulan

1. Penulis dapat mengetahui sistem kerja yang ada pada pembayaran keterlambatan pembayaran premi nasabah pada berry anggara 1446 cabang Lampung.

2. perhitungan denda dibuat berdasarkan waktu periode pembayaran premi

3. Dengan menggunakan sistem ini informasi ini diharapkan dapat memberikan pelayanan kepada nasabah dengan cepat dan akurat 


\section{Manual Books Article Task}

\section{ACKNOWLEDGEMENT}

University Of Indonesia University Of Mitra Indonesia Telkom University University Of Mellbourne Saitama University

\section{REFERENCES}

3. A. S. Putra, H. Sukri, and K. Zuhri, "SistemMonitoring Realtime Jaringan Irigasi Desa (JIDES)DenganKonsep Jaringan Sensor Nirkabel," IJEIS (Indonesian J. Electron. Instrum. Syst., vol. 8, no. 2, pp. 221-232.

4. D. P. Sari, O. M. Febriani, and A.

Putra, "Perancangan Sistem Informasi SDM Berprestasi pada SD Global Surya," in Prosiding Seminar Nasional Darmajaya, 2018, vol. 1, no. 1, pp. 289-294.

5. A. S. Putra, "Paperplain: Execution Fundamental Create Application With Borland Delphi 7.0 University Of Mitra Indonesia," 2018.

6. A. S. Putra, D. R. Aryanti, and I. Hartati, "Metode SAW (Simple Additive Weighting) sebagai Sistem Pendukung Keputusan Guru Berprestasi (Studi Kasus: SMK Global Surya)," in Prosiding Seminar Nasional Darmajaya, 2018, vol. 1, no. 1, pp. 85-97.

7. A. S. Putra and O. M. Febriani, "KnowledgeManagement Online Application in PDAM LampungProvince,"in Prosiding International conference on Information Technology and Business (ICITB), 2018, pp. 181-187.

8. A. S. Putra, O. M. Febriani, and Bachry, "Implementasi Genetic Fuzzy System Untuk Mengidentifikasi Hasil Curian Kendaraan Bermotor Di Polda Lampung," SIMADA (Jurnal

Sist. Inf. dan Manaj. Basis Data), vol. 1, no. 1, pp. 21-30, 2018.

4. A. S. Putra, "2018 Artikel Struktur Data, Audit Dan Jaringan Komputer," 2018.

5. O. M. Febriani and A. S. Putra, "Sistem Informasi Monitoring Inventori Barang Pada Balai Riset Standardisasi Industri Bandar Lampung," J. Inform., vol. 13, no. 1, pp. 90-98, 2014. 
